\title{
Promoting Rural Development through Chieftaincy Institutions and District Assemblies: Evidence from Sissala East District, Upper West Region of Ghana
}

\author{
Dominic Degraft Arthur \\ Department of Culture and Global Studies \\ Faculty of Humanities, Aalborg University, Denmark \\ Email:kwakye16o@yahoo.com \\ and \\ Tanko Daniel Dawda \\ Department of Social, Political and Historical Studies \\ University for Development Studies, Wa Campus, Ghana \\ Email:tankod@yahoo.com \\ DOI//http://dx.doi.org/10.4314/gjdsv12i1\&2.10
}

\begin{abstract}
The study examines the contribution of the District Assembly and Chieftaincy Institution in promoting rural development. The purpose was to provide empirical data on the contribution of the District Assembly and Chieftaincy Institution as stakeholders in the rural development agenda of local government in Ghana. This is against the backdrop of several criticisms and challenges confronting the Chieftaincy Institution, which have put the integrity of the institution in question in the Local Government System of Ghana. In this study, local government actors including heads of decentralized department, assembly members and district assembly staff were purposively sampled from the district. Household heads and chiefs were sampled from eight communities in the Sissala East District of the Upper West Region, Ghana for the study. Four focus group discussions were conducted. The findings of the study reveal that the District Assembly and Chiefs have contributed in diverse ways to enhance development of the communities in the District. The contributions include playing advocacy role to enlighten the local citizenry in the area of payment of rates and taxes, their active involvement in elections (National and District) and the provision of watchdog role towards state properties in the communities of the District. Consequently, there is the need for collaboration between the two institutions in local governance processes to ensure effective partnership for sustainable rural development.
\end{abstract}


Keywords: Local Government, Chieftaincy Institution, Sustainable Development, Traditional Authorities

\section{INTRODUCTION}

Ghana, like any other country in Africa, during the pre-independence era, considered chieftaincy as a key institution around which Ghanaian society could build its developmental programmes. The chiefs were not democratically elected representatives of the British colonial administrators, but were personally hand-picked (Hailey, 1951). The decisions taken by the chiefs on key issues concerning rural level development had to reflect not only their wishes, but those of the local citizenry as a whole (Hailey, 1951). As Owusu (1989) puts it, constitutionally, chiefs held their positions in a fiduciary capacity and had obligations to use the resources, wealth and power at their disposal for the welfare of the entire population and not of a selected privileged few in their areas of jurisdiction within the district councils of Ghana. Yet, despite the pervasive nature of the chieftaincy institution, in 1961 through Act 54 under Nkrumah's government, the traditional representation on district councils was abolished in Ghana. Afterwards, Act 54 of the 1961 Constitution mandated the members who wished to represent their constituents in the district councils to go through election, and the President of the council, who was a Paramount Chief, was made to be appointed by the Minister of Justice to preside over the meetings of the council (Okyere, 2000).

Unlike the erstwhile regime, in 1969, Busia's government reinstated the chieftaincy institutions in Ghana. The Chapter 16 of the 1969 Constitution was devoted to Chieftaincy and the Local Government System spelt out the compositions of the membership of traditional authorities in the Local, District and Regional Councils in Ghana. Like the previous regime, General Akuffo and his Supreme Military Council Two (SMC II) government which took over the state's power in 1979 also recognized the relevance of the traditional chiefs in the District Councils. For example, Chapter 20 of the 1979 Republican Constitution provided for an Act of Parliament to establish District Councils and two-thirds of whose membership was to be elected by universal adult suffrage and one-third were to be appointed by the traditional authorities (Okyere, 2000). Like the preceding governments, under the civilian government of the People's National Party (PNP), which came to office in September, 1979, an attempt was made in August 1981 to add forty districts to the existing district councils to increase the total to one hundred and five districts. However, before the proposal could be executed the Provincial National Defense Council (PNDC) toppled the Peoples' Progress Party (PNP) administration on $31^{\text {st }}$ December, 1981 and took over power from the PNP government. In June, 1982, the PNDC passed PNDC Law 14 to dissolve the elected district councils and the representation of traditional authorities in district councils in November 1978. Management committees nominated by the PNDC appointed District Secretaries to replace the councillors (Amponsah \& Boafo-Arthur, 2003). Subsequently, in December 1983, the PNDC government promulgated a new policy on decentralization, which sought 
to increase initiative on rural development in the district councils of Ghana. The intention was to mitigate the migration of local people from the local communities to towns for basic public services (Amponsah \& Boafo-Arthur, 2003). As Ayee (1994) notes, the 1983 decentralization programme did not make any reference to the election of the local representatives primarily because the mainstream institutions of the People's Defense Committees (PDCs) and Workers Defense Committees (WDCs) within the PNDC were considered to be the suitable representative institutions to work in the District Councils.

Unlike the erstwhile regimes which preceded the PNDC administration, under Article 276 (1) of the 1992 Constitution, the chiefs were barred from taking part in active political activities in Ghana. Although Article 270 of the 1992 Constitution of the Republic of Ghana, guaranteed the establishment of the chieftaincy institution, together with its traditional councils as recognized by customary law and usage, the institutions' role in local level development had not been formalized in the Constitution. By implication, the chieftaincy institution which used to have legislative, judicial and executive powers to oversee, supervise, encourage and promote rural level development was marginalized under the 1992 Constitution. Against this background, chiefs have not been given any representation in the new Local Government structure under the 1992 Constitution. Following from this constitutional provision, Ahwoi (2010) emphasizes that, although the 1992 Constitution places statutory limitations on traditional authorities, the chieftaincy institution remains resilient, and continues to perform not only the traditional and customary roles, but also other key developmental roles to enhance local level development at their local areas of jurisdiction. In light of the foregoing discussions, the question is: To what extent do the chieftaincy institution and district assembly help to promote rural development in the Sissala East District of Ghana? To examine the preceding central research question, the paper is divided into five broad sections. The first section of the paper focuses on the introduction. The second section is focused on the review of the relevant literature. The third section is devoted for the methodology. The fourth section discusses the findings, and the final section concentrates on the conclusions of the study.

\section{Literature Review}

Dependency theory emerged in the latter parts of 1950s. The emergence of dependency theory was the response to the conventional approaches to economic development, which emerged after the Second World War. For example, scholars including Gunder (1981) notes that classical development theories such as modernity is deceptive theory primarily because the modernity theory failed to provide the true correlation that exists between the developed and poor regions within the globe. In support of this view, Gunder (1981) states that modernization theory changes the truth about the intention of the developed countries on their previous colonies. Brandt's (1980) Commission which comprised elder statesman, men and women of stature" established by the United Nations in 1977 revealed 
that development based on modernity had failed. In congruence to the preceding stance, Reid (1995) argued:

The trust that more rapidly economic growth "modernization" in third world countries by itself would benefit the large masses of poor people has not been fulfilled, and no concept of development can be accepted since more than hundreds of millions of people continue to live in starvation and despair (Reid, 1995).

Justifying the preceding view, Gunder (1981) notes that the core principle of dependency theory at the macro level is that in reality it would not be possible to appreciate the processes and struggle of Africa without taking into account the wider-historical context of Western European growth in both industrial and mercantile capitalism coupled with the colonization of places by the Western economies. For example, Rodney (1972) in his investigation of the impact of colonization on developing countries emphasizes that, colonialism was not only a system of exploitation, but also a colonial policy which sought to repatriate the profits made in Africa to the developed countries. Seen in this light, Rodney concludes that repatriation of profits signifies a systematic extradition of the surplus values that was produced by Africa labour using Africa resources towards the growth of developed world. According to Rodney, the development of Europe can be viewed as part of the same dialectical processes that underdeveloped Africa.

Samir, Chaitala and Mandaza's (1987:2) evaluation of the relationship between the developed countries and Africa in the colonial period found out that African countries during the colonial period were depending on the developed countries on political, economic and cultural facet of life. In their view, African countries dependence on the developed countries continues to persist in the post - colonial period. Arguably, the authors reveal that such dependence of the African continent on the developed countries is not an isolation case. Even within Africa, dependence is also obvious between rural areas and the urban areas. This reflects the fact that while the developed countries are anxiously exploiting Africa; the urban areas within Africa are also seriously exploiting their rural areas.

Drawing an example to support the foregoing stance, Tom (1991) posits that Amarthole in South Africa, Lower Gweru, Chibi, Mhondoro Chirmanzi and many more districts in Zimbabwe experienced underdevelopment arising from the incidence of exploitation. In this light, Tom (1991) believes that poverty at all levels is a consequence of inhibiting conditions (internal colonialism); relationships between the developed communities (urban areas) and their satellites (rural areas) as well as between individuals with diverse economic powers.

As Rodney (1972) notes, the dependency theory has made Africa a dumping ground for surplus manpower and waste, and a market where the terms of trade work in favour of the giant and developed countries. According to Rodney, Africa is strategically placed to focus on marketing raw materials, whilst on the one hand, the developed world market 
the end products. In support of this standpoint, Ndulu (2004) emphasizes that Africa leaders must be blamed for creating the opportunity for the developed world to exploit the continent after about six decades of independence. For example, Ndulu points out that by signing the World Trade Organization (WTO) agreements in 1995, Africa has relinquished a lot of its economic might for development to the developed world. As a follow - up to the earlier contributions, Rodney (1972) contends that the crucial ideology of dependency school rests on the premise that development of the developed countries was a consequence of the active underdevelopment of the Africa countries. According to Rodney, human resources from Africa have migrated and continue to move away to the developed world for greener pastures. In his view, the extraction of the human capital out of the Africa to the developed world is another kind of slavery; which is in resemblance with the slave trade which hit Africa continent during the fifteen and the early nineteenth century. This viewpoint of Rodney (1972) supports Gunder's (1981) previous work that underdevelopment of Africa is not the unique state, but it had its roots from the economic capture and control by the advanced countries (Gunder, 1981).

According to Tom (1991), the dynamics surrounds the impoverishment operation adopted by the developed world is entirely depressing. In Tom's (1991) viewpoint, the developed countries succeeded to annihilate the traditional and pre - capitalist social institutions of Africa through missionary education with the view to exploit the Africa countries, resulting not only on the underdevelopment of the satellite, but on the development of the metropolis. In view of that, Tom (1991) concludes that, the dependency theory is exploitative and thus impoverishing the African countries. This theory is adopted as the framework to explain why Africa and for that matter Ghanaian rural communities are underdeveloped, and the need for collaboration by the Chieftaincy Institutions and District Assemblies in promoting rural development.

\section{The Role of Chiefs as Partners in Rural Development}

The role of the chieftaincy institution in rural development cannot be overestimated in developing countries. In Ghana, the involvement of chiefs in promoting economic development features prominently in the work of Kendie and Guri (2007). According to Kendie and Guri (2007), throughout the world, culture is one of the institutions that enforce the rules, norms and values of the people, because the authority and structure of these institutions are clearly defined and this is also applicable to the traditional institutions in Ghana. In the viewpoints of Kendie and Guri (2007), the chieftaincy institution demonstrates the significant legitimacy of traditional leaders and their potential ability to influence their subjects in development programmes and projects.

As a follow-up to the earlier contributions, Kendie and Guri (2004) in their research: "Traditional institutions, culture and development" argued that Non-Governmental 
Organizations (NGOs) and other development agents have side - lined the traditional institutions and authorities in their development programmes largely because the traditional institutions and authorities do not always conform to western worldviews and criteria for development agenda. The preference is for externally facilitated agents such as Community Based Organizations (CBOs) and Faith-Based Organizations (FBOs) that do not incorporate indigenous knowledge, practices and criteria of the communities in rural development policies. According to Kendie and Guru (2004), the failure to involve the traditional authorities in the rural development policies and programmes has a strong predilection to discourage the traditional authorities towards initiating developmentoriented activities in their areas of jurisdiction to enhance rural development. In view of that Kendie and Guri (2004) opine that, indigenous institutions such as the "Asafo" group 4 , the clan, and chieftaincy institution have their in-built capacity for ensuring sustainable process of rural development. Thus, any programme of activity that nurtures, adapts and supports community initiatives originating from such institutions and organizations would pave the way for sustainable development. Hence, these local institutions are important conduits for internal mobilization and sustenance for local level development.

Assimeng's (2001) study: "The chieftaincy institutions in Ghana" has generally tended to improve our knowledge on the role of traditional rulers in their communities in Ghana. According to Assimeng (2001), traditional rulers are significant in the decentralized administration because they perform a multiple roles of military leader, spiritual head, administrator of justice, the overlord of peace and order in their areas of jurisdiction. Therefore, this enables the local citizens to have confidence in them because they are able to provide some essential basic local services to meet the needs and aspirations of the local people within the state.

Millar (2002) also reveals that traditional rulers are one of the key actors in the maintenance of natural resources. For example, Millar (2002) argues that the spirituality aspects of the functions of traditional rulers in Ghana helps to instil fear in those subjects who perform acts contrary to the dictates of sound environmental management in their areas of jurisdiction. As Millar (2002) puts it, "traditional rulers perform sound environmental management function effectively in their local areas of jurisdiction to support the Metropolitan, Municipal and District Assemblies (MMDAs) to improve environmental cleanliness in the districts".

In support of the preceding view, Seyonjo (2002) emphasizes that traditional rulers are key stakeholders in dispute resolution in Ghana in particular and Africa in general. Seyonjo believes that, apart from the formal administrative courts of law, the traditional courts serves as an alternative mode of conflict resolution mechanism in Ghana. In his viewpoint, the traditional courts operate in communities where there is poor access to

4 Asafo group is a group of people comprising of elders and youths who serve as the militia in the communities. The group helps to provide community security and local level development in the communities. 
the formal administrative courts for conflict resolutions within the state. The traditional court system serves as security and thereby help to protect the welfare and life of the community members in the local areas of the state.

\section{District Assemblies as Partners in Rural Development}

There are five perspectives of the role of local government in development; these are traditional fiscal federalism, new public management, public choice, new institutional economies, and network forms of local governance (Shah, 2006). According to Mawhood (1988) the traditional fiscal federalism and the New Public Management perspective are concerned primarily with market failures and how to deliver public goods efficiently and equitably. In the viewpoints of Mawhood (1988), two interrelated criteria have emerged from the traditional fiscal federalism and New Public Management literature; first, what local governments should do and, second, how they should do it better. In support of this view, Mawhood (1988) contends that the literature assumes that citizens are the principals, but have multiple roles as governors (owners, authorizers, voters, tax payers, community members); activists-producers (providers of services, co-producers, selfhelpers obliging others to act); and consumers (clients and beneficiaries). Mawhood (1988) argues that significant emphasis is placed on the government as an agent of the people to serve the public interest and create public value at the local level. This concept is relevant to local and municipal services for which it is feasible to measure such improvements and have some sense of attribution. The concept is useful in evaluating conflicting and perplexing choices in the use of local resources, and also in defining the role of local governments in the state.

In addition, public choice and new institutional economies perspectives are concerned with government failures. The scholars of the Public Choice and the New Institutional Economies School of thought have provided an evaluation framework for alternative forms and mechanisms of local governance. According to the Shah (2006), the evaluation framework provides guidance in dealing with government failures in a hierarchical form of public governance, and also suitable for examining local government involvement in partnership with multiple organisations. Shah (2006) emphasizes that the network form of governance relies on trust, loyalty, and reciprocity between partners with no formal institutional safeguards such as traditional institutions in developing countries of Asia and Africa.

Discussing the networks form of governance as one of the perspectives of local government in development, Moore (1999) reveals that the perspective is concerned with institutional arrangements and linkages to overcome both market and governmental failures to improve the delivery of basic local goods and services to the people. According to Moore (1999), the perspective focuses on building a relations between formal government structures and traditional authorities especially in most developing countries. In the viewpoint of Moore (1999), these linkages are important elements for the successful implementation of projects to enhance local level development. 


\section{METHODOLOGY}

\section{The Study Area}

Sissala East District which serves as one of the basic units of Local Government in Ghana is located in the north-western part of Ghana. The administrative district capital is Tumu. The District is strategically positioned as it shares a 300 kilometre border with Burkina Faso to the North. The district shares boundaries to the east with Kassena Nankana East and Builsa District, both of the Upper East Region, while its extreme south eastern position shares a boundary with Mamprugo - Moaduri District of the Northern Region. To West, the District shares boundaries with Sissala West and to the South, Wa East (Sissala East District Assembly, 2014). Sissala East District with its headquarters in Tumu, was created in 2004 through the legislative instrument (LI 1766) in pursuant of the policy of decentralization started in 1988. Sissala East District has one constituency with twentyone electoral areas. The District has a population of 56,528 . About $83.0 \%$ of the population live in areas classified as rural, whist only $17.0 \%$ population live in urban communities (Ghana Statistical Service, 2012).

As regards distribution of settlements according to the sizes, Sissala East District has a population of 56, 528 (female 29,025 and male 27,050). It can be concluded that apart from Tumu town, most of the settlements are basically rural although there are isolated towns with a population of above 2000. In fact Tumu, which is an important commercial centre is the most populous town in the district (Ghana Statistical Service, 2012). The key reason for this kind of population distribution trends in the Sissala East District is that Tumu town provides the highest first level services in health, education, finance, administration justice and security, commerce and transportation and other services which include resource mobilization, peace building and community needs identification in the District. Consequently, people from other parts of the communities within the Sissala East District prefer to stay and work in Tumu in order to get access to these services (Sissala East District Assembly, 2014). The District has two main chieftaincy paramouncies; the Tumu paramouncy and the Walembelle paramouncy with their respective divisional chiefs and sub-chiefs. Sissala East District is an excellent case study to examine the contributions of the Chieftaincy institution and District Assemblies in promoting rural development primarily because Sissala East District is a growing Local Government unit in Ghana with several developmental challenges and aspirations that require the attention of researchers.

Qualitative methodology was used to undertake this study. The qualitative data was collected between February 25 to March 24, 2014 through in-depth interviews and focus group discussions. Qualitative research was utilized in the study because the study sought to generate in-depth understanding on the experiences of the respondents on the role of the District Assembly (DA) and Chieftaincy Institution on rural development. The study was located in the Sissala East District of the Upper West Region, Ghana. The respondents were purposively selected from eight communities in the district. In all twenty household 
heads and eight chiefs from eight communities were contacted for this study. Some officials were selected from the Sissala East District Assembly. They included the District Chief Executive, the Presiding member, fifteen Assembly members, five representatives of NGOs and the District Coordinating Director. The purposive sampling method was used primarily because they were the key informants, and therefore had in-depth knowledge on the issue of study. Altogether, there were fifty-one respondents for the study. Data gathered through in-depth interview and focus group discussions were supplemented with the published and unpublished scholarly materials that were used in the analysis to arrive at the conclusions.

\section{DISCUSSION OF FINDINGS}

\section{Role of District Assembly and Traditional Chiefs in Rural Development}

The role of the DA towards rural development falls within the national development policy framework. This mandatory role of the DAs covers social, economic, infrastructural and environmental programmes. To find out the role played by the Sissala East District Assembly in rural development, a question was asked to solicit the views of the assembly staff concerning the district's development programmes. Discussions with the assembly officials revealed that in terms of education, the DA has constructed classroom blocks for day nurseries, primary schools, junior high schools and senior high schools in the district through the use of the Internally Generated Revenue (IGF) and the District Assembly Common Fund (DACF). The assembly officials opined that the DA has provided classroom blocks to the communities with pre-school programmes in order to improve the level of education in the communities. As the respondents maintained, although the policy of the education sector mandates the communities to manage pre-school education, yet, the DA has assisted and in majority of cases funded the total cost of the provision of nursery structures for the communities. Interactions with the DA staff also revealed that the DA has constructed at least one teachers' bungalow for basic schools in Sakai, Wellembelle, Manduanu, Nabulo, Nubugubelle, Bugubelle, Kulfuo, Sakalo and Bujan.

On health care delivery system, the study found out that the DA has constructed and rehabilitated several health facilities in the district to provide quality health care for the people. These include health post in Nabulo, Kulfuo, Sakalo, Bujan and Sakai. The DA has also constructed six staff bungalows over the last five years in Tumu, Sakai, Wellembelle, Manduanu, Sakalo and Nabulo for nurses. The district health director revealed that the District Health Administration in partnership with the DA has been sponsoring fourteen nurse trainees who are expected to support the existing staff of the district health centres after their training programmes.

The DA in partnership with Ghana Water Company Limited, Community Water and Sanitation Agency and other water-related organisations had provided water services to communities in the area. The communities had different types of water supply systems; 
these included boreholes, hand-dug wells and dams. The DA had provided seventy-two boreholes, seventeen hand-dug wells and three dams from 2008 to 2012. On the road network system, the study found out that the DA has constructed thirty-four kilometres stretch of feeder roads and reshaped one hundred and eighty-six kilometres over the past five years through the assistance of the Department of Feeder Roads. Furthermore, the district officials revealed that the District Feeder Roads through the support of the District Assembly in March 2013 constructed new feeder roads linking Sakalo to Sentie, and another linking Walembelle and Bichemboi. The road network system is about eightyseven percent complete. In addition, the DA has repaired and constructed twenty-six broken bridges damaged through torrential rains in the district over the past five years.

\section{Participation of Chiefs in Rural Development}

Technically, one of the key issues to the successful operation of decentralization under local government programmes is the active participation of the beneficiaries in shaping the decisions that affect them. The reason is that, the potential benefits of local information and human resources cannot be realized and rural development accelerated, if the people at the grassroots are not made active participants in the shaping of decisions. Actually, the very essence of local government since the colonial era is the urge to make governance local, that is, as close to the people as possible (Olowu, 1999). For instance, Article 240, section (2e) of the 1992 Constitution states that "to ensure the accountability of local government authorities, people in particular local government areas shall, as far as practicable, be afforded the opportunity to participate effectively in their governance (Republic of Ghana, 1993). In Ghana, the irony is that, the 1992 Constitution did not give traditional chiefs any representation in the district assembly, despite the fact that, traditional chiefs are identified as agents of development.

However, to investigate the contribution of chiefs on rural development, we asked the respondents (chiefs) whether they would be interested if given the opportunities to participate in active politics in the DA programmes?. It became apparent during the interaction that the chiefs would have been interested in taking active part in politics at the DA levels of the state. The chiefs further emphasized that, though, they are debarred from active politics both at the national and local units of the state, they (chiefs) continue to help to release parcels of land for development projects. Again, they help promote progressive traditional values, norms and culture in their area of jurisdiction. For example, the Chief of Tarsaw outlined his viewpoints to support the role of chiefs in Sissala East District Assembly as follows:

Chiefs helped the community members to respect the accepted practices within the community and sanctioned deviants who did not comply. At the community level, general issues of cultural socialisation were ensured by the traditional authorities in their respective areas. Chiefs also acted as agents through whom people were mobilised to undertake communal labour. These norms and values essentially serve as guiding 
principles to the local people in their bid to contribute to self-help initiated projects in their communities. (Field work, March 2014).

The role of chiefs in the management and resolution of disputes in consultation with the district security council was explored. The chief of Nabulo outlined his views as follows:

General issues of theft, fighting and land disputes are settled at the chief's palace since we do not have police stations, therefore, things cannot get done in the community without the involvement of the chiefs. Chiefs and their elders provide direction and guidance to the people in their communities. Though some of them can be autocratic and self-centred, they provide security to the people in the communities (Field work, March, 2014).

Admittedly, the responses from the field through the interviews and focus discussions confirm the observation by Kangsangbata and Kendie (2009) that dispute resolution would have been impossible without the active involvement of chiefs. On revenue mobilisation, the study found out that chiefs in collaboration with the District substructures such as the Area Councils and Unit Committees play an advocacy role to enlighten the local citizenry to know their civic responsibilities in a state. These included the payments of rates and taxes, taking active part in communal labour, elections (both national and district) protection of state properties, and providing watchdog roles in communities. During the interactions with the household heads, it became clear that the advocacy role of chiefs was helping positively in the area of revenue mobilisation. The household heads emphasized that sometimes the chiefs used their own financial resources to undertake projects for the communities with little or no assistance from the DA. The findings suggest that the local level managers such as chiefs are often sensitive to the opinions and needs of their people, consequently, their involvement in local level governance is important for rural development.

\section{CONCLUSION}

Local government institutions in Ghana, especially the District assemblies under the decentralization policy are considered as the linchpin of rural development. This is important in view of the fact that the ultimate aim of all governments is "development." Nevertheless, under the banner of decentralization, governments have introduced policies that concentrate power and decision - making in the centre and weaken rural communities in promoting development. For example, under Ghana's decentralization policy, serious devolutions have been rare. In addition, the deconcentration or the establishment of mixed authorities in the District assemblies have been the favoured approach for the policy makers in the state.

However, in order for the local government system under the decentralization to work to achieve the target of promoting development, policy makers need to be more innovative 
and resourceful so that they can take advantage of the community values, norms, traditions and chieftaincy institutions to support the state-sponsored programmes to promote rural development. This is critical largely because chiefs still hold significant authority because they generally represent the highest levels of social control in their communities in Ghana. As the study demonstrates, projects and programmes can be effectively implemented in a sustainable manner if traditional authorities are involved in all processes of the local government and rural development agenda. As a result there is the need for an effective collaboration between traditional chiefs and formal local government actors in the planning and implementation of local development programmes to promote rural developments.

\section{References}

Ahwoi, K. (2010). Local government and decentralisation in Ghana. Accra. Ghana institute of management and public administration, GIMPA.

Amponsah, N. and Arthur - Boafo, K. (2003). Local government in Ghana. Grassroots participation in the 2002 local government elections. Uniflow publishing limited Ghana.

Assimeng, M. (2001). The chieftaincy institution in Ghana. Konard Adenaur Foundation.

Ayee, J. R .A. (1994). An anatomy of public policy implementation. The case study of decentralization policies in Ghana. Avebury Aldershot.

Brandt, R. (1980). North-south: A programme for survival. The report of the independent commission on international development issues. London. Pan Books.

Ghana Statistical Service. (2012). Ghana population and housing census. Accra: Ghana.

Gunder, A. F. (1981). Crisis in the third world. New York: Holmes and Meier publishers.

Hailey, L. (1951). Native administrator in the British Africa territories. London: HMSO.

Kangsangbata C. and Kendie S. B. (2009). The role of traditional authorities in local governance. Oguaa Journal of Social Sciences.

Kendie, S.B. and Guri, B. Y. (2004). Traditional institutions, culture and development. The "Asafo" group in the Mankessim Nkwanta traditional area. Centre for development studies, Cape Coast, university of Cape Coast.

Kendie S. B. and Guri, B. Y. (2007). Indigenous institutions, governance and development. Community mobilisation and natural resource management in Ghana. Endogenous Development and Bio-cultural Diversity. 
Mawhood, P. (1988). Local government in the third world. The experiment of tropical Africa. Chichester. John Wiley and sons.

Millar, D. (2002). Traditional authorities and land administration: A Case of Wenchi traditional area of southern Ghana. Bolagatanga, Ghana. Centre for cosmos vision and indigenous knowledge.

Moore, M. (1999). The job ahead. In community, opportunity, responsibility, accountability -report of the symposium on the future of public services. Washington DC.Office of Public Management.

Ndulu, B.J. (2004). Human capital flight: Stratification, globalization, and the challenges to tertiary education in Africa. JHEA/RESA.

Okyere, N. v. (2000). Ghana: A historical survey. Accra: Royal Crown Press Ltd.

Olowu, D. (1999). Local government democracy and development. In Richard Joseph Boulder Lynne Rienner (ed.) In state conflict and democracy.

Owusu, M. (1989). Rebellion, revolution and tradition. Reinterpreting coups in Ghana. Comparative studies in society and history.

Reid, D. (1995). Sustainable development. An introductory guide. London: Earthscan Publications Ltd.

Republic of Ghana. (1993). Local government law (Act 462). Accra: Ghana PublishingCorporation.

Rodney, W. (1972). How Europe underdeveloped Africa. Dar es Salaam: Tanzanian Publishing House.

Samir, A., Chitala, D. and Mandaza, I. (1987). SADCC, prospects for disengagement and development in Southern Africa. Studies in Africa political economy. United Nations University. London: ZED Books Ltd.

Sissala East District Assembly. (2010). Sissala east district medium term development plan, (2006-2010).

Seyonjo, J. (2002). Traditional institutions and land. Accessed: December 26, 2014 from http://federo.com/pages/ traditional institutions and land htm.

Shah, A. (2006). A comparative institutional framework for responsive, responsible, and accountable local governance. In (Rev. Ed.) Local Governance in Industrial Countries. Public sector governance and accountability series: The International Bank for Reconstruction and Development/the World Bank.

Tom, G. (1991). The human factor in rural development. London: Belhaven press. 